Abstracta Iranica Abstracta Iranica

Revue bibliographique pour le domaine irano-aryen

Volume 42-43 | 2021

Comptes rendus des publications de 2019-2020

\title{
Pauline Niechciał. "Calendar as an Identity Marker of the Zoroastrian Community in Iran"
}

Alberto Bernard

\section{OpenEdition}

Journals

Édition électronique

URL : https://journals.openedition.org/abstractairanica/54001

DOI : 10.4000/abstractairanica.54001

ISSN : 1961-960X

Éditeur :

CNRS (UMR 7528 Mondes iraniens et indiens), Éditions de l'IFRI

Référence électronique

Alberto Bernard, «Pauline Niechciat." Calendar as an Identity Marker of the Zoroastrian Community in Iran" », Abstracta Iranica [En ligne], Volume 42-43 | 2021, document 2, mis en ligne le 30 décembre 2021, consulté le 14 décembre 2022. URL : http://journals.openedition.org/abstractairanica/54001 ; DOI : https://doi.org/10.4000/abstractairanica.54001

Ce document a été généré automatiquement le 14 décembre 2022.

Tous droits réservés 


\title{
Pauline Niechciał. "Calendar as an Identity Marker of the Zoroastrian Community in Iran"
}

\author{
Alberto Bernard
}

\section{RÉFÉRENCE}

Pauline Niechciał. "Calendar as an Identity Marker of the Zoroastrian Community in Iran", Iran and the Caucasus 23 (2019), p. 35-49

1 Depuis au moins le Moyen Âge, les différents calendriers et les façons diverses de les calculer ont fait objet de débat parmi les communautés zoroastriennes. En montrant que ceci est encore le cas aujourd'hui, l'A. en étudie les enjeux socio-culturels et la dialectique à la fois intracommunautaire (calendrier bāstānī vs qadīmī etc.) et politique (rapport avec le calendrier de l'État) qui se produit. Elle analyse aussi la symbolique des calendriers physiques produits dans la communauté zoroastrienne de Téhéran. Dans son double aspect conceptuel et matériel, le calendrier zoroastrien de la communauté de Téhéran se révèle non seulement (ce qui est normal) un marqueur d'identité mais aussi un véhicule d'idées sur l'enracinement « iranien » des zoroastriens (imagerie du fravahar, des fêtes anciennes, des héros mythiques etc.). 


\section{AUTEURS}

\section{ALBERTO BERNARD}

Doctorant EPHE, CeRMI, Paris 